\section{Цитування:}

Ільницька О. А. Цирковий костюм як засіб художньо-образної виразності. Вісник Національної академії керівних кадрів культури $і$ мистеитв : наук. журнал. 2021. № 1. С. 237-241.
Ільницька Олександра Анатолї̈вна, асистент, Київський національний університет культури і мистеитв

ORCID: https://orcid.org/0000-0002-0733-8165 ilnitskaya_aleksandra@.ukr.com

Ilnitskya O. (2021). Circus suit as a means of artistic expression. National Academy of Culture and Arts Management Herald: Science journal, 1, 237-241 [in Ukrainian].

\title{
ЦИРКОВИЙ КОСТЮМ ЯК ЗАСІБ ХУДОЖНЬО-ОБРАЗНОЇ ВИРАЗНОСТІ
}

Мета дослідження - виявити специфіку костюму як виражального засобу циркового мистецтва, а також розглянути його функцію як формотворчого компонента циркового видовища та визначити роль та можливості циркового костюма в процесі створення образу. Методологія дослідження. Застосовано метод мистецтвознавчого аналізу та системний метод, що посприяли систематизації виражальних засобів циркового мистецтва; метод художньо-стилістичного аналізу та типологічний метод 3 метою виявлення специфіки означеного художньо-виражального засобу і виявлення основних ненаративних форм створення 3 його допомогою циркового образу; метод структурного аналізу циркових номерів (для виявлення особливостей сприйняття глядачем візуального ряду в цілому та ролі в його формуванні циркового костюма) та ін. Наукова новизна. Досліджено цирковий костюм як один із засобів виразності циркового мистецтва; виявлено особливості сприйняття костюму в цирковому номері та актуальні тенденції його використання в контексті впровадження новітніх технологій створення циркового видовища; охарактеризовано специфіку еволюції циркового костюма на сучасному етапі розвитку виконавських мистецтв в цілому та циркового зокрема. Висновки. Цирковий костюм - важливий засіб виразності сучасного циркового мистецтва призначений для посилення образності та художності циркової програми в цілому та номеру зокрема, що органічно поєднуючись 3 музичним оформленням, реквізитом, апаратами або снарядами, освітленням, пластичним або хореографічним рішенням і впливає на глядача в межах художнього образу. Дослідження виявило, що розробка циркового костюма як виражального засобу базується на аналізі характеру трюкової роботи в номері, врахуванні комплексу фізико-механічних та естетичних особливостей тканин, органічному поєднанні 3 іншими виражальними засобами відповідно образному баченню постановника. Відмінним $є$ функціональне призначення циркового костюма в сюжетному та безсюжетному цирковому номері: у першому випадку костюм створює конкретний художній образ та посилює сенсово-змістову складову номеру, а в другому - $є$ не лише заявкою на манежний образ артиста, а фактично візуальною суттю цього образу. Сучасні циркові костюми характеризуються унікальністю композиційного характеру, що відображає інтерпретаційну логіку постмодернізму і виражається в сенсовій грі, новаторській стратегії використання історично стилістики та ін.

Ключові слова: цирковий костюм; циркове мистецтво; виражальні засоби; емоційне сприйняття; візуальний ряд; художній образ.

Ilnitskya Oleksandra, assistant, Kyiv National University of Culture and Arts

Circus suit as a means of artistic expression

The purpose of the article is to identify the specifics of the costume as an expressive means of circus art, as well as to consider its function as a formative component of a circus show and to determine the role and capabilities of a circus costume in the process of creating an image. Methodology. The method of art history analysis and the systemic method were applied, which contributed to the systematization of the expressive means of circus art; the method of artistic and stylistic analysis and the typological method in order to identify the specifics of a certain artistic and expressive means and the main non-creative forms of creating a circus image with its help; the method of structural analysis of circus performances (to identify the peculiarities of the viewer's perception of the visual series as a whole and the role in its formation of the circus costume), etc. Scientific novelty. The circus costume is investigated as one of the means of expressiveness of circus art; the peculiarities of the perception of the costume in the circus act and the current trends of its use in the context of the introduction of the latest technologies for creating a circus show are revealed; the specificity of the evolution of the circus costume at the present stage of the development of the performing arts in general and circus in particular is characterized. Conclusions. The circus costume is an important means of expressiveness of modern circus art, which is intended to enhance the imagery and artistry of the circus program in general and the performance in particular, organically combining with musical design, props, apparatus or projectiles,

СІльницька О. А., 2021 
lighting, plastic or choreographic solutions and affects the viewer within artistic image. The study revealed that the development of a circus costume as an expressive means is based on the analysis of the nature of the stunt work in the room, taking into account the complex of physical, mechanical and aesthetic features of fabrics, organic combination with other expressive means in accordance with the imaginative vision of the director. The functional purpose of the circus costume in a plot and plotless circus performance is excellent: in the first case, the costume creates a specific artistic image and enhances the semantic and content component of the performance, and in the second, it is not only an application for an arena image of the artist but in fact is the visual essence of this image. Modern circus costumes are characterized by the uniqueness of their compositional character, which reflects the interpretational logic of postmodernism and is expressed in a semantic game, an innovative strategy for using historical stylistics, etc.

Key words: circus costume, circus art, expressive means, emotional perception, visual range, artistic image.

Актуальність теми дослідження. Історія циркового мистецтва засвідчує постійний пошук унікальної власної мови, специфічних засобів циркової виразності, що не доступні жодному іншому мистецтву. Стрімкий розвиток циркового мистецтва початку XXI ст. у напрямку пошуку різноманітних форм виразності та розширення сенсово-змістового аспекту циркових номерів актуалізує дослідження та переосмислення основних засобів виразності циркового артиста. Цирковий костюм - важливий елемент постановки циркового номера, допоміжний виражальний засіб, що разом із освітленням, музичним оформленням та реквізитом формує індивідуальність постановки, сприяє розкриттю образу.

У зв'язку 3 тенденцією посилення візуальної складової циркового видовища на сучасному етапі, важливою $є$ теоретизація особливостей використання костюма в цирковому номері 3 метою розширення наукової бази циркознавства як самостійної галузі сучасного мистецтвознавства.

Мета дослідження - виявити специфіку костюму як виражального засобу циркового мистецтва, а також розглянути його функцію як формотворчого компонента циркового видовища та визначити роль та можливості циркового костюма в процесі створення образу.

Аналіз досліджень. Проблематиці різноманітних аспектів циркового мистецтва загалом та виражальних засобів, зокрема, на сучасному етапі вітчизняними науковцями приділена неабияка увага. Серед останніх досліджень та публікацій назвемо наукові праці Т. Гріньє «Нова буфонада як складова сучасних тенденцій розвитку циркового мистецтва» [3], Ю. Ніколаєвої «Шляхи формування та розвитку циркової та естрадної клоунади» [5], О. Поспєлов «Сучасний стан і перспективи розвитку циркової галузі України» [6], С. Шумакової «Харківська творча майстерня циркового мистецтва: типологія постановочних тенденцій» [8] та ін., у яких проаналізовано специфіку синтезу цирку та естради в історичній ретроспективі, виявлено сучасні тенденції розвитку буфонади, досліджено видовищну сутність та особливості розвитку циркових жанрів у контексті міжвидового та міжжанрового інтегрування елементів видовищних форм мистецтва, здійснено спробу типологізувати еволюційні тенденції постановочної практики творчих майстерень циркового мистецтва та iH.

Проте костюм як один із засобів виразності циркового мистецтва не став предметом окремого дослідження, що актуалізує розгляд означеного питання.

Виклад основного матеріалу. Мова, форми, художня природа та засоби виразності унікальні для кожного виду мистецтва, надають індивідуальні властиві прийоми, створюють неповторну лексику, особливі способи створення художнього образу. При цьому художні засоби будь-якого виду мистецтва взагалі та циркового мистецтва зокрема, не лишаються незмінними, а незворотньо змінюються в динаміці розвитку.

У контексті специфіки дослідження розуміємо виражальні засоби циркового мистецтва як сукупність певних прийомів, методів, способів діяльності циркового артиста, а допоміжні засоби виразності як сукупність засобів різних видів мистецтва, використовуючи які створюється та посилюється художньо-естетична вартість i емоційний вплив циркового номеру.

Головним завданням циркового мистецтва, на думку дослідників, $\epsilon$ формування художньо-естетичного та культурного розвитку суспільства за допомогою використання засобів пластичної виразності, раціонального підходу до пізнавальної активності та можливості подолання ризику засобами удосконалення кінетичного досвіду людини. В. Барінов акцентує на тому, що побудова дії циркового номера на основі парадоксу, алогізму та абсурду надзвичайно приваблива 3 точки зору подачі відомого життєвого матеріалу в новаторських формах, а виражальна мова цирку сприяє максимальному розкриттю дійсності в усьому їі багатоманітті $[1,170]$. На 


\section{Вісник Національної академії керівних кадрів культури і мистецтв № 1'2021}

сучасному етапі зміни відбуваються не лише в естетиці та стилістиці циркового номера, але і в цирковій лексиці, формах та способах презентації, а також структурі номерів.

Циркове мистецтво поєднує різноманітні жанрові різновиди, спільність яких полягає в органічному пристосуванні до різних умов публічної демонстрації, короткочасності дії та концентрації художніх виражальних засобів, що сприяють яскравому виявленню творчої індивідуальності артиста.

Специфіка циркового мистецтва (зовнішній ефект $є$ одним із основоположних законів), зумовила широке використання артистами так званої маски - певного образу, який вирізняється постійністю біографії, властивостей характеру та зовнішнього вигляду, а всі засоби виразності спрямовані на створення протягом короткого часу (хронометрах окремих циркових номерів не перевищує 3-х хвилин) місткого, емоційно сильного образу.

Принцип інтегрування необхідних для розкриття образу елементів (засобами циркового костюма, реквізиту, музичного оформлення, хореографії, снарядів та ін.) історично проявився у тенденції відбору основних та допоміжних виражальних засобів 3 урахуванням характеру трюкової роботи в конкретному цирковому жанрі.

Специфіка циркового мистецтва передбачає звернення артиста до глядача засобами унікальної трюкової мови, що визначає загальностильове забарвлення номеру.

Функціональне призначення циркового костюма вирізняється для сюжетного та безсюжетного номера. У випадку створення сюжетного номера артист використовує багату палітру виражальних засобів циркового мистецтва, одним 3 яких $\epsilon$ тематичний сценічний костюм. Метою його застосування $\epsilon$ створення на «навіювання» глядачу конкретний художній образ, що посилює сенсово-змістову складову номеру. В сюжетному номері цирковий костюм не лише сприяє посиленню яскравості видовища, але й виконує інформаційну функцію (форма та лінії повідомляють про час дії, а деталі та доповнення - про соціальний статус, характер, смак та звички персонажа).

У безсюжетному цирковому номері роль допоміжних виражальних засобів не менш актуальна: костюм, як правило, стає не лише заявкою на манежний образ, що створюється артистом, а фактично візуальною суттю цього образу. Проте в окремих жанрах циркового мистецтва костюм традиційно $є$ умовним, спрямованим на створення не конкретного, а відстороненого, узагальненого образу. Наприклад, традиційні види циркових виробничих костюмів як балетна пачка (еквілібр на дроті, повітряна акробатика, вища школа верхової їзди), камзол та трико (для вершника), парадна форма приборкувача хижих тварин, яскраві ексцентричні костюми партерного акробата або музичного ексцентрика, трико та рейтузи повітряного акробата та ін.

На думку дослідників, костюм циркового артиста доцільно розглядати як матеріальний предмет, що використовується в цирковому номері і наділений духовно-знаковим ефектом зовнішнього та змістового впливу - він емоційно налаштовує глядача, посилює вплив циркової дії, передає почуття виконавця, доповнює i пояснює дію, позиціюється як продовження думки або як «другий план». Це складова художнього образу артиста, зовнішні ознаки та характеристика зображуваного ним персонажу. А. Фальковський наголошує, що для циркового костюма характерне стильове різноманіття історичних, фольклорних, спортивних та побутових форм i видів минулого та сучасності, а також фантастичні та казкові оригінальні костюми [7, 43]. Наприклад, класичними цирковими костюмами вважаються туніки та плащі доби Середньовіччя, а також каптан, камзол, редінгот (різновид костюму для занять верховою їздою), фрак, смокінг наступних історичних періодів (строгі та елегантні, вільні та зручні за формами та кроєм, що підкреслюють особливості фігури артиста), а традиційними стереотипами одягу гусарський, мисливський, ковбойський та факірський костюми.

В. Даркевич стверджує, що 3 часів Середньовіччя жонглерів упізнавали за «кричущим «клаптевим» одягом», а придворних жонглерів - за двоколірними «гербовим одягом» 3 діагональними візерунками та поперечними смугами або шаховою кліткою $[4,70]$.

Дослідники наголошують на відмінних аспектах створення та розвитку багатоманіття форм i видів циркових та театральних костюмів, що зумовлено професійнохудожніми та виробничо-технологічними законами та нормами. Зокрема, особливого значення набувають структурні та інші характеристики конкретної тканини в контексті органічної взаємодії 3 тілесною роботою артиста (гнучкість, розтягувальні властивості, легкість та щільність, прозорість та міцність, а також стійкість фарби i необхідна для певних фізичних навантажень практичність тканини). $\mathrm{y}$ процесі 
конструювання циркового костюму враховуються комплекс фізико-механічних (структура, товщина, щільність, міцність, пружність та ін.) та естетичних (фактура, малюнок, колір, орнаментика) особливостей тканин [7, 56]. Наприклад, для повітряних номерів типовим $\epsilon$ використання костюмів тканин, що струмують. Асоціативність $\epsilon$ важливим методом використання сценічного костюма.

Для циркового мистецтва початку XXI ст. характерна надзвичайна інтенсивність розвитку, багатоманіття напрямів, яскравість індивідуальностей виконавців. Трансформації сучасного соціокультурного простору, нові суспільні стосунки та життєвий устрій посприяли появі нових форм та засобів виразності циркового мистецтва, а також еволюції традиційних, що передбачає руйнування усталених канонів.

На сучасному етапі розвитку циркового мистецтва поруч із технічними інноваціями, мультимедійними технологіями, еволюцією жанрів та розширенням репертуару посилюється роль високохудожнього циркового костюма, який розглядається 3 дуалістичних позицій його художньоестетичної та практичної цінності.

Оскільки сучасний цирк вирізняється цілісністю видовища - замість підготовлених та розроблених окремими артистами серії номерів, сучасні циркові програми характеризуються розгортанням послідовностей 3 визначеною тематичною та естетичною єдністю, а у випадку адаптації літературного першоджерела - створенням відповідної атмосфери $[10,17]$; однією 3 провідних тенденцій світового циркового мистецтва $є$ розвиток діяльності «театрівцирків», у постановках яких власну майстерність демонструють повітряні гімнасти, жонглери, фокусники, акробати, клоуни та ін. $[9,44]$ новий напрямок, тематика та зміст циркових постановок зумовлюють новаторські образні рішення, форми та способи їх вираження в цирковому костюмі. Зокрема, розширюється коло виражальних засобів та прийомів, креативно використовується сучасні технології, зокрема, нові спеціально розроблені матеріали дозволяють поліпшити форму, крій та колір циркового костюма, наближуючи його до характеру та жанру номера, що сприяє кращому емоційному сприйняттю глядачем трюку як основного виражального засобу циркового мистецтва.

\section{Костюм}

характеризується

відмінностями та сучасного

цирку місткими стильовими особливостями, вражає глядача сміливістю та неординарністю художнього рішення; відмовою від прямого використання класичних закономірностей композиції та переходом до інтуїтивного мислення 3 підвищеною асоціативністю та метафоричністю,

багатогранністю (наприклад, костюми, створені відомим художником і дизайнером Р. Розелло для французьких цирків Cirque Arlette Gruss Profitez

Cirque d'Hiver Bouglione та швейцарського Circus Knie). Проте традиційні специфічні саме для циркового костюму нюанси - спеціальні технічні та трюкові пристосування лишаються їх відмінною характеристикою.

Особливості мистецтва постмодернізму, що відобразилися на трансформації циркового мистецтва початку XXI ст. стали передумовою позиціювання циркового костюма як антитектонічного твору, в якому архітектонічні принципи (властивості усіх природних, технічних, архітектурних та художніх форм, що пов'язані з їх оптимальним функціонуванням та естетичною цінністю) [2, 5] порушуються свідомо та демонстративно 3 метою досягнення ефекту несподіваності, загадкової невизначеності та оригінальності задуму.

Висока сучасна культура циркового мистецтва, тонка i глибинна режисерська діяльність над цирковими номерами та програмами в цілому, майстерність артистів наразі вимагає від художника по костюму ретельного занурення в драматургію постановки. Відповідно до специфіки соціомистецького простору перших десятиліть XXI ст. оформлення циркових програм не канонізується жорсткими правилами, воно є індивідуальним i конкретним у кожному приватному випадку.

Наукова новизна. Досліджено цирковий костюм як один із засобів виразності циркового мистецтва; виявлено особливості сприйняття костюму в цирковому номері та актуальні тенденції його використання в контексті впровадження новітніх технологій створення циркового видовища; охарактеризовано специфіку еволюції циркового костюма на сучасному етапі розвитку виконавських мистецтв в цілому та циркового зокрема.

Висновки. Цирковий костюм - важливий засіб виразності сучасного циркового мистецтва призначений для посилення образності та художності циркової програми в цілому та номеру зокрема, що органічно поєднуючись 3 музичним оформленням, реквізитом, апаратами або снарядами, освітленням, пластичним або хореографічним 


\section{Вісник Національної академії керівних кадрів культури і мистецтв № 1’2021}

рішенням i впливає на глядача в межах художнього образу.

Дослідження виявило, що розробка циркового костюма як виражального засобу базується на аналізі характеру трюкової роботи в номері, врахуванні комплексу фізикомеханічних та естетичних особливостей тканин, органічному поєднанні 3 іншими виражальними засобами відповідно образному баченню постановника. Відмінним $\epsilon$ функціональне призначення циркового костюма в сюжетному та безсюжетному цирковому номері: у першому випадку костюм створює конкретний художній образ та посилює сенсово-змістову складову номеру, а в другому - $\epsilon$ не лише заявкою на манежний образ артиста, а фактично візуальною суттю цього образу. Сучасні циркові костюми характеризуються унікальністю композиційного характеру, що відображає інтерпретаційну логіку постмодернізму і виражається в сенсовій грі, новаторській стратегії використання історично стилістики.

\section{Лimepamypa}

1. Баринов B. А. Феномен цирка в современной культуре. Общественные науки и современность. 2012. № 3. С. 168-176.

2. Бердник Т. О. Архитектоника костюма: социокультурная динамика : автореферат дис. канд. философских наук : 24.00.01 / Ростовский государственный университет. Ростов-на-Дону, 2004. $28 \mathrm{c}$.

3. Гріньє Т. Б. Нова буфонада як складова сучасних тенденцій розвитку циркового мистецтва. Культура України. 2018. Вип. 61. С. 282-289. DOI: https://doi.org/10.31516/2410-5325.061.028.

4. Даркевич В. П. Народная культура средневековья. Москва : Наука, 1988. 342 с.

5. Николаева Ю. Г. Пути формирования и развития цирковой и эстрадной клоунады. Культура. Наука. Творчество : Х Международная научно- практическая конференция: сборник научных статей. Минск, 12 мая 2016 г. Белорусский государственный университет культуры и искусств. Минск, 2016. Вып. 10. С. 340-345.

6. Поспєлов О. О. Сучасний стан і перспективи розвитку циркової галузі України. Сучасні дослідження в галузі культури і мистецтв : матеріали III-ї Міжнародної заочної науковопрактичної конференції. Київ, 26 квітня 2018. Київ : КНУТКТ імені I. К. Карпенка-Карого, 2018. С. 6063.

7. Фальковский А. Художник в цирке. Москва : Искусство, 1978. 143 с.

8. Шумакова С. Н. Харьковская творческая мастерская циркового искусства: типология постановочных тенденций. Вестник Харьковской государственной академии дизайна и искусств. 2015. № 1. C. 58-65.

9. Martinez A. La dramaturgie du cirque contemporain Français: quelques pistes théâtrales.
L'Annuaire théâtral : revue québécoise d'études théâtrales. 2002. $\mathrm{n}^{\circ} \quad 32$. pp. 12-21. DOI: 10.7202/041501ar.

10. Mogliani L. Historia del circo en Buenos Aires. De los volatineros a la formación universitaria. Buenos Aires : Universidad Nacional de Tres de Febrero. 2017. URL https://www.academia.edu/41022741/HISTORIA_DE L_CIRCO_EN_BUENOS_AIRES_De_los_volatineros _a_la_formación_universitaria (дата звернення : 1 лютого 2021).

\section{References}

1. Barinov, V. A. (2012). The phenomenon of circus in modern culture. Social sciences and modernity, no. 3, pp. 168-176 [in Russian].

2. Berdnik, T. O. (2004). Architectonics of the costume: socio-cultural dynamics. Phd thesis. Rostovon-Don : Rostov State University [in Russian].

3. Grinier, T. B. (2018). New buffoonery as a component of modern trends in circus art. Culture of Ukraine, Issue 61, pp. 282-289. DOI: https://doi.org/10.31516/2410-5325.061.028 [in Ukrainian].

4. Darkevich, V. P. (1988). Folk culture of the Middle Ages. Moscow: Nauka [in Russian].

5. Nikolaeva, Yu. G. (2016). Ways of formation and development of circus and variety clowning. Culture. The science. Creativity: $X$ International Scientific and Practical Conference: collection of scientific articles. Minsk, May 12, 2016 Belarusian State University of Culture and Arts. Minsk, Issue. 10, pp. 340-345 [in Russian].

6. Pospelov, O. O. (2018). Current state and prospects of development of the circus industry of Ukraine. Modern research in the field of culture and arts: materials of the III International correspondence scientific-practical conference. Kyiv, April 26, 2018. Kyiv: IK Karpenko-Kary KNUTKT, pp. 60-63 [in Ukrainian].

7. Falkovsky, A. (1978). Artist in the circus. Moscow: Art [in Russian].

8. Shumakova, S. N. (2015). Kharkov creative workshop of circus art: typology of staging trends. Bulletin of the Kharkov State Academy of Design and Arts, no. 1, pp. 58-65 [in Russian].

9. Martinez, A. (2002). La dramaturgie du cirque contemporain Français: quelques pistes théâtrales. L'Annuaire théâtral : revue québécoise d'études théâtrales, no 32. pp. 12-21. DOI: 10.7202/041501ar [in French].

10. Mogliani, L. (2017). Historia del circo en Buenos Aires. De los volatineros a la formación universitaria. Buenos Aires : Universidad Nacional de Tres de Febrero. URL https://www.academia.edu/41022741/HISTORIA_DE L_CIRCO_EN_BUENOS_AIRES_De_los_volatineros _a_la_formación_universitaria [in Spanish].

Стаття надійшла до редакиії 22.09.2020 Отримано після доопрачювання 08.10.2020 Прийнято до друку 13.10.2020 